\title{
THE CALIBRATION OF A WEIGHTED DISC AGAINST PASTURE DRY MATTER YIELD
}

\author{
D. S. M. Phillitps and S. E. ClaArke \\ Ruakura Agricultural Research Centre, Hamilton
}

\section{Summary}

A simple pasture yield meter based on the use of a weighted metal disc is described. The device has been calibrated against pasture dry matter yield from mowing machine cuts over all seasons and a range of pasture types.

\section{INTRODUCTION}

\&N-DESTRUCTIVE methods of estimating grass yield have been described previously and are of two types. The radio\&frequency capacitor type of meter (Campbell et al., 1962) has been widely used in research work. Simpler techniques have been based on .an estimate of mean grass height by placing a rigid sheet on the grass and measuring the average distance from the ground (Jagtenburg, 1970). Difficulties in reading mean grass height have been overcome in the grass meter described here, by attaching the weighted metal plate to a shaft carried in a vertical guide mounted on a tripod. The scale is rigidly mounted on the tripod and accurate measurements of the compressed height can be made after a predetermined settling time. The device was calibrated against mowing machine cuts made on trial plots.

\section{MATERIALS AND METHODS}

The grass meter is shown in Fig. 1 and consists of a metal plate $14 \mathrm{in}$. in diameter attached to a vertical metal shaft which slides in a smooth bearing held by a tripod. The distance of the plate from the ground can be measured on the scale mounted on the top of the tripod stand. The downward movement of the disc can be stopped after a predetermined "settling" time by operation of a small brake which engages a friction pad with the vertical shaft. The settling time is measured with a stopwatch mounted on the tripod., and the brake is applied by a toggle lever which can be tripped quickly. 


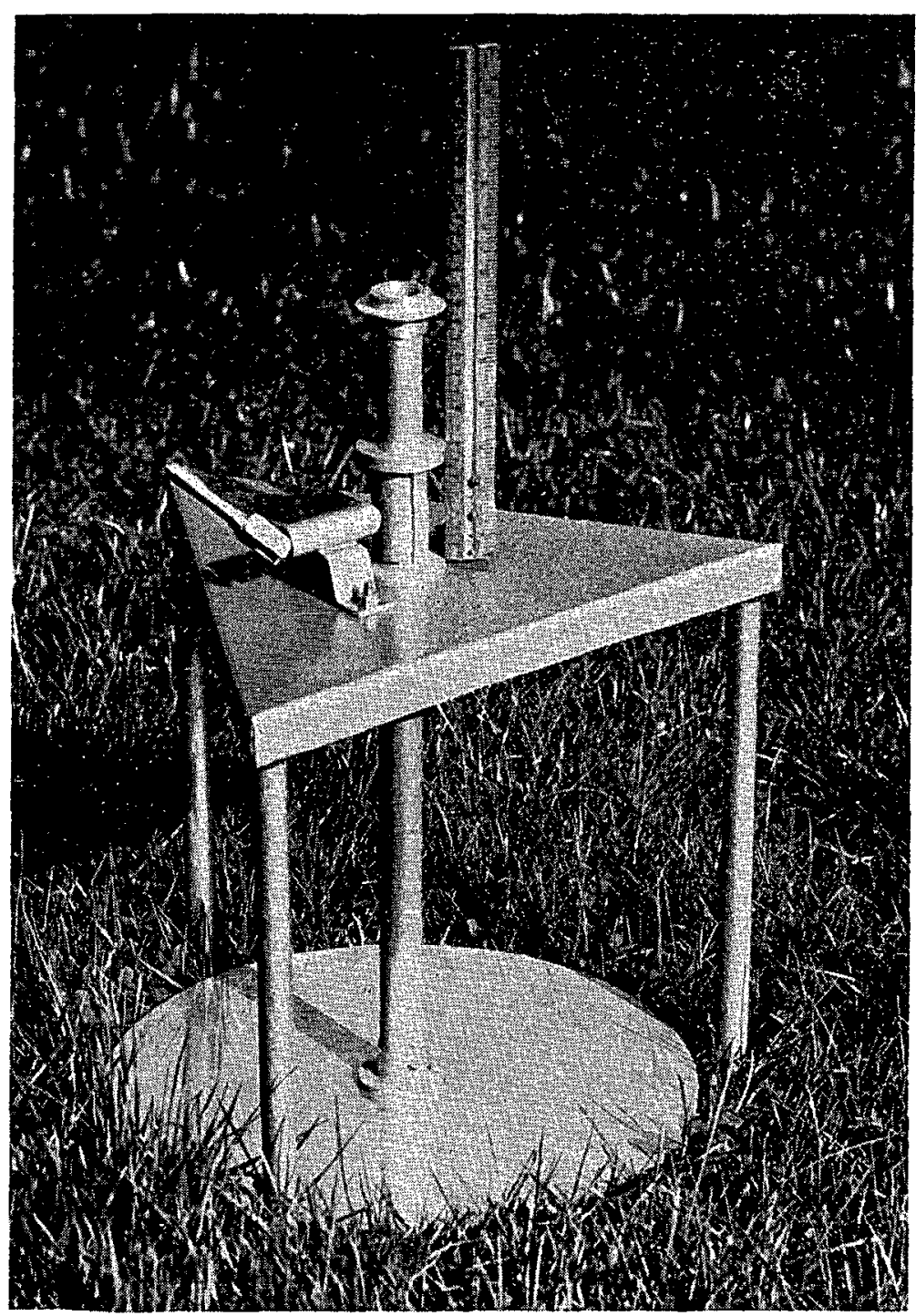

FIG. 1: The weighted-disc

mefer in use. The lever in fhe left foreground operates the brake which is applied after a pre-determined settling time.

In use it was found that a settling time of $10 \mathrm{sec}$ was convenient. The total weight of the disc and shaft assembly could be varied by using a selection of lead weights which were placed 
on the upper end of the shaft. In the initial model a polythene bearing was used but experiments are being made with the use of PTFE* to reduce friction.

\section{SENSITIVITY}

The sensitivity of the instrument was estimated by measuring the daily growth of several grass plots. Independent daily measurements were made on a number of marked plots to estimate the repeatability and sensitivity of the method.

Calibration Against Pasture dry Matter Yield

The instrument was calibrated against pasture dry matter yield from mowing machine cuts on a number of trial plots throughout the year. The plots consisted of two strips $20 \mathrm{ft}$ long on which grass meter measurements were made at $2 \mathrm{ft}$ intervals. Mowing machine cuts were then made by:

(a) Sickle-bar mower cuts $3 \mathrm{ft}$ wide.

(b) Reel mower cuts 20 in. wide.

In each case the yield of grass was calculated on a per-acre basis, and dry matter determinations were made from samples taken from the cut.

\section{PASTURE TYPE}

Pasture type was variable but tended to be grass-dominant in spring and winter and highly clover-dominant in summer and autumn.

\section{Visual Estimates Compared}

Comparisons were made with visual estimates of yield made by three experienced technicians on twenty plots.

\section{RESULTS}

Growth curves for two plots are given in Fig. 2. In each case two disc weights were used. The addition of the $2 \mathrm{lb}$ weight to the disc and shaft appeared to give a more consistent reading but further investigation of the effect of weight is warranted, particularly in regard to its effect with variations in pasture composition.

A typical plot of data for the spring peroiod is given in Fig. 3. The pasture yield was obtained by combining the figures for both sickle-bar and reel-mower cuts.

\footnotetext{
*Polytetrafluroethylene
} 
TABLE 1: SICKLE-BAR MOWER - REGRESSION OF DRY MATTER WEIGHT/ACRE ON DISC HEIGHT

\begin{tabular}{|c|c|c|c|c|c|c|c|c|c|}
\hline \multirow[b]{2}{*}{ Season } & \multirow[b]{2}{*}{$\begin{array}{l}\text { No. of } \\
\text { Sample } \\
\text { Plots }\end{array}$} & \multirow[b]{2}{*}{$\begin{array}{c}\text { Mean } \\
D M / a c r e \\
(l b)(y)\end{array}$} & & \multirow[b]{2}{*}{$\begin{array}{l}\text { Mean } \\
\text { D M \% }\end{array}$} & \multirow[b]{2}{*}{$\begin{array}{c}\text { Correlation } \\
\text { Coefficient } \\
\qquad(r)\end{array}$} & \multicolumn{3}{|c|}{$\mathbf{y}=b x+\mathbf{a} \pm r . s . d}$. \\
\hline & & & $\begin{array}{c}\text { Standarc } \\
\text { E rror } \\
\text { (sy) }\end{array}$ & $\begin{array}{c}\text { Mean Disc } \\
\text { Height } \\
(\mathrm{cm})(x)\end{array}$ & & & b $\pm S . E$ & a & $\begin{array}{l}\text { Residual } \\
\text { Std. } \\
\text { Deviation }\end{array}$ \\
\hline Winter & 8 & 480 & 211 & 6.3 & 13.2 & 0.94 & $186 \pm 27$ & -691 & 75 \\
\hline \multirow[t]{3}{*}{ Spring } & 8 & 924 & 321 & 9.0 & 12.1 & 0.98 & \multirow{3}{*}{$147 \pm 9$} & -399 & \multirow{3}{*}{99} \\
\hline & 9 & 698 & 309 & 8.3 & 13.3 & $0.94\}-$ & & $-517\rangle \dagger$ & \\
\hline & 12 & 877 & 335 & 9.3 & 14.4 & 0.95 & & $-486)$ & \\
\hline \multirow[t]{2}{*}{ Summer } & 6 & 1.084 & 332 & 8.7 & 16.2 & $\left.{ }^{0.87)}\right\}$ & \multirow[t]{2}{*}{$218 \pm 23$} & $\begin{array}{r}-700) \\
\}\end{array}$ & \multirow[t]{2}{*}{ ** } \\
\hline & 7 & 1,901 & 725 & $11.4-$ & 17.7 & $0.97)$ & & 584 & \\
\hline \multirow[t]{2}{*}{ Autumn } & 6 & 1,053 & 255 & 6.5 & 12.7 & $0.96\}$ & \multirow{2}{*}{$133 \pm 28$} & $184\}$ & \multirow[t]{2}{*}{124} \\
\hline & 6 & 1,502 & 181 & 10.3 & 11.2 & 0.71 & & 127 & \\
\hline
\end{tabular}

tP $10.10 * P<0.05 \quad * * P<0.01$ 
TABLE 2: REEL MOWER CUT. REGRESSION OF DRY MATTER WEIGHT/ACRE ON DISC HEIGHT

\begin{tabular}{|c|c|c|c|c|c|c|c|c|c|c|}
\hline \multirow[b]{2}{*}{ Season } & \multirow{2}{*}{$\begin{array}{l}\text { No. of } \\
\text { Sample } \\
\text { Plots }\end{array}$} & \multirow{2}{*}{$\begin{array}{c}D M / \text { acre } \\
(l b)(z)\end{array}$} & \multirow[b]{2}{*}{$\begin{array}{r}\text { Error } \\
(s z)\end{array}$} & \multirow{2}{*}{$\begin{array}{c}\text { M ean } \\
\text { D isc-H ei ght } \\
(\mathrm{cm})(x)\end{array}$} & \multirow[b]{2}{*}{$\begin{array}{l}\text { Mean } \\
\text { D M \% }\end{array}$} & \multirow[b]{2}{*}{$\begin{array}{l}\text { Correlation } \\
\text { Coefficient } \\
\quad(r)\end{array}$} & \multicolumn{3}{|c|}{$\mathbf{z}=\mathbf{b x}+\mathbf{a} \pm r . s . d$} & \multirow[b]{2}{*}{$\begin{array}{c}z= \\
(b \pm S . E .) \\
\mathbf{b} \pm \mathbf{S . E .}\end{array}$} \\
\hline & & & & & & & $b \pm \mathbf{S . E .}$ & 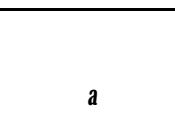 & $\begin{array}{l}\text { Residual } \\
\text { Std. } \\
\text { Deviation }\end{array}$ & \\
\hline & & & & & & & $* *$ & & & \\
\hline Winter & 8 & 1,007 & 220 & 6.3 & 13.2 & 0.89 & $183 \pm 39$ & 143 & 109 & $160 \pm 6$ \\
\hline \multirow[t]{3}{*}{ Spring } & 8 & 1,488 & 367 & 9.0 & 12.1 & $0.98)$ & $* * *$ & 37) & \multirow{3}{*}{113} & $166 \pm 3$ \\
\hline & 9 & 1,113 & 355 & a. 3 & 13.3 & $0.99\}$ & \multirow{2}{*}{\multicolumn{2}{|c|}{$\mathbf{1 6 1} \pm 11$}} & & $137 \pm 4$ \\
\hline & $\begin{array}{c}12 \\
\text { Pooled }\end{array}$ & 1,403 & 350 & 9.3 & 14.4 & 0.93 & & & & $\begin{array}{l}151 \pm \mathbf{4} \\
151 \pm 3\end{array}$ \\
\hline \multirow[t]{2}{*}{ Summer } & 6 & 1,601 & 445 & 8.7 & 16.2 & $0.91)$ & \multirow{2}{*}{$\begin{array}{c}221 \neq * 4 \\
225\end{array}$} & \multirow{2}{*}{$\left.\frac{-308-j}{0}\right\}^{3 * * * *}$} & \multirow[b]{2}{*}{210} & $187 \pm 10$ \\
\hline & $\begin{array}{c}7 \\
\text { Pooled }\end{array}$ & 2,519 & 694 & 11.4 & 17.7 & 0.96 & & & & $\begin{array}{l}220 \pm \\
210 t\end{array}$ \\
\hline \multirow[t]{2}{*}{ Autmn } & 6 & 1,549 & 289 & 6.5 & 12.7 & 0.90 & \multirow{2}{*}{$\begin{array}{c}* * * * \\
189 \pm 28\end{array}$} & $315 \mid$ & \multirow[t]{2}{*}{125} & 235-c 9 \\
\hline & $\begin{array}{c}6 \\
\text { Pooled }\end{array}$ & 1,960 & 293 & 10.3 & 11.2 & 0.93 & & $9 \mid$ & & ${ }^{190-c}{ }^{190} \pm 7^{4}$ \\
\hline
\end{tabular}

$\uparrow P<0.10 \quad * P<{ }^{\prime} 0.05 \quad * * P<0.01 \quad * * * P<0.001$ 


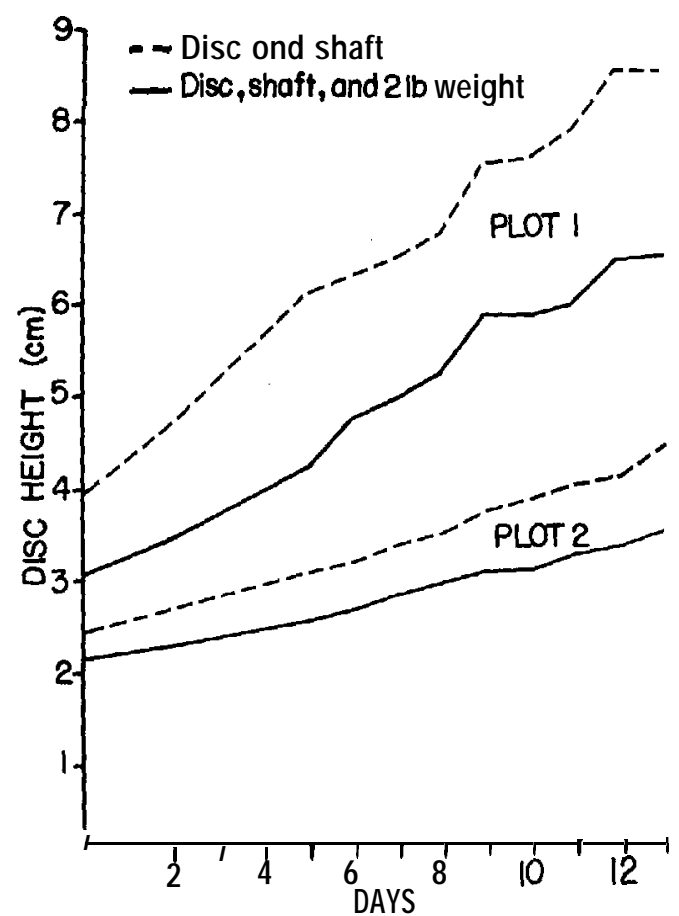

FIG. 2: Daily growth readings made with weighted-disc grass-meter on two plots, with disc and shaft weight only, and with an additional $2 \mathrm{lb}$ weight.

The data were examined statistically and regression analyses are given in Tables 1 and 2. Data were grouped into periods of approximately a fortnight, as time appeared to be a factor influencing the regression.

In the case of the reel-mower cuts, the regression was also fitted to pass through the origin. While this is not likely to be

TABLE 3: CORRELATIONS BETWEEN GKASS-METER AND VISUAL ESTIMATES AND DRY MATTER WEIGHT PER ACRE

\begin{tabular}{|c|c|c|c|}
\hline Operator & $\begin{array}{c}\text { Correlation } \\
\text { Coefficient } \\
(r)\end{array}$ & $\begin{array}{c}r \\
\text { Omitting } \\
\text { one plot of } \\
3,840 \mathrm{lb} / \mathrm{ac}\end{array}$ & $\begin{array}{l}\text { Spearman's } \\
\text { Rank } \\
\text { Correlation }\end{array}$ \\
\hline Grass-meter & 0.91 & 0.90 & 0.92 \\
\hline Visual estimates: & & & \\
\hline $1 \quad \ldots \ldots$ & 0.82 & 0.90 & 0.93 \\
\hline.$\quad$. & 0.73 & 0.87 & 0.88 \\
\hline$\ldots \ldots$ & 0.75 & 0.87 & 0.87 \\
\hline
\end{tabular}




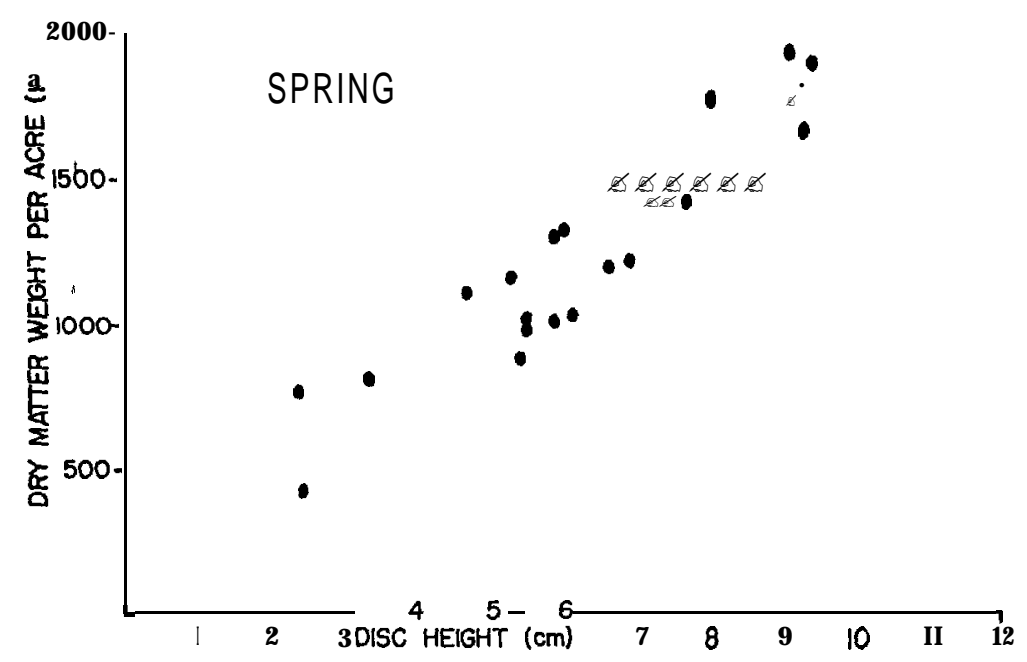

FIG. 3: of weighted-disc grass-meter readings againsf reel-mower cuts in Ib dry matter per acre for the spring period.

the case in fact, it may well be sufficient for practical purposes if very low levels of grass are not being measured.

Correlations of mower-cut yield with visual estimates and meter reading for the same plots are given in Table 3.

The meter was superior to all operators only in estimating the yield of one high yielding plot which was underestimated in all visual assessments. Otherwise the meter was comparable with the best visual estimate.

\section{DISCUSSION}

With care in reading the scale the repeatability of readings was surprisingly high. The fact that daily increments in growth could be detected indicates a high level of sensitivity.

It was noticeable that summer and autumn periods produced pastures of high clover dominance. This may well account for the marked shift in the regressions for these periods relative to spring and winter. It is possible that pasture composition could be used to provide a correction factor, or alternatively a different weight could be used.

There was no correlation between dry matter percentage and meter indication. 
For practical use the meter could probably be calibrated for different times of the year depending on the type of pasture. As a rough approximation from the present data the following factors could be used:

Summer and autumn (clover) - $205 \mathrm{lb} \mathrm{DM} / \mathrm{ac}$ for every $\mathrm{cm}$ of meter scale.

Spring and winter (grass) - $155 \mathrm{lb} \mathrm{DM} / \mathrm{ac}$ for every $\mathrm{cm}$ of meter scale.

It is possible, however, that the scale would be directly graduated in $\mathrm{lb} \mathrm{DM} / \mathrm{ac}$ and corrections could be applied for pasture type by the use of two different weights. Further studies will determine the best methods of correcting for the variables encountered in practice.

The meter is capable of detecting relativeiy small differences in pasture growth and is better than a skilled technician in estimating total dry matter yield. At the same time, the use of the meter is less tiring than visual estimation.

The meter has many advantages over more complex measuring devices such as the radio-frequency grass-yield meter. It is extremely simple in construction and can be duplicated exactly with ease. It does not suffer from calibration drift due to battery or temperature changes. It is mechanically robust' and will not readily lose calibration owing- to mechanical changes resulting from mild abuse. The wetness or electrical conductivity of the pasture is unlikely to have any effect on the indicated yield.

No skill is required in its operation, thus it is very suitable for general field use. Its simplicity and low cost may well extend its usefulness to the technically able farmer who could benefit from an unbiased assessment of pasture yield. Such a device has already been suggest\&d as a means of estimating fertilizer needs (Jagtenburg, 1970) and the grass meter described here could be a real aid to pasture management in grassland farming.

\section{ACKNOWLEDGEMENTS}

Thanks are due to $\mathrm{C}$. During who revived the interest in this meter after nine years on the shelf, and to D. Duganzich and the Biometrics Section for statistical analysis. Credit is also due to the Art and Photographic Department for rhe illustrations.

\section{REFERENCES}

Campbell, A. G.; Phillips, D. S. M.; O'Reilly, E. D., 1962: J. Br. Grassld Soc., 17: 90-100.

Jagtenberg, W. D., 1970: J. Br. Grassld Soc., 25: 266-71. 